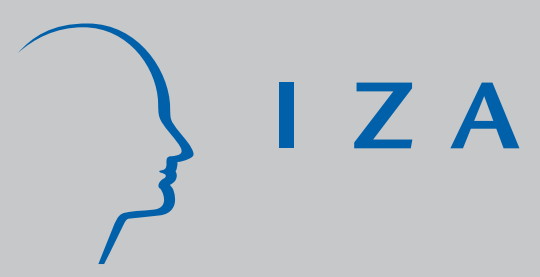

IZA DP No. 1591

Is Marriage Poisonous? Are Relationships Taxing? An Analysis of the Male Marital Wage Differential in Denmark

Nabanita Datta Gupta

Nina Smith

Leslie S. Stratton

May 2005 


\title{
Is Marriage Poisonous? Are Relationships Taxing? An Analysis of the Male Marital Wage Differential in Denmark
}

\author{
Nabanita Datta Gupta \\ Danish National Institute of Social Research, CIM \\ and IZA Bonn \\ Nina Smith \\ Aarhus School of Business, CIM \\ and IZA Bonn \\ Leslie S. Stratton \\ Virginia Commonwealth University, CIM \\ and IZA Bonn
}

Discussion Paper No. 1591

May 2005

IZA

P.O. Box 7240

53072 Bonn

Germany

Phone: +49-228-3894-0

Fax: +49-228-3894-180

Email: iza@iza.org

Any opinions expressed here are those of the author(s) and not those of the institute. Research disseminated by IZA may include views on policy, but the institute itself takes no institutional policy positions.

The Institute for the Study of Labor (IZA) in Bonn is a local and virtual international research center and a place of communication between science, politics and business. IZA is an independent nonprofit company supported by Deutsche Post World Net. The center is associated with the University of Bonn and offers a stimulating research environment through its research networks, research support, and visitors and doctoral programs. IZA engages in (i) original and internationally competitive research in all fields of labor economics, (ii) development of policy concepts, and (iii) dissemination of research results and concepts to the interested public.

IZA Discussion Papers often represent preliminary work and are circulated to encourage discussion. Citation of such a paper should account for its provisional character. A revised version may be available directly from the author. 


\section{ABSTRACT \\ Is Marriage Poisonous? Are Relationships Taxing? An Analysis of the Male Marital Wage Differential in Denmark*}

The word for 'married' in Danish is the same as the word for 'poison'. The word for 'sweetheart' in Danish is the same as the word for 'tax'. In this paper we expand upon the literature documenting a significant marital wage premium for men in the United States to see if a similar differential exists for married men in Denmark - or if the homonyms have perhaps less of a double meaning. Unlike most other research in this area, our study is based on a large panel sample with complete relationship histories, consisting of about 35,000 young Danish men observed before and after their first marriage or cohabitation during the years 1984-2001. Since the majority of young Danes cohabit before they marry, if they ever marry, cohabitation is allowed for as a separate state. Pooled OLS estimates indicate a marital wage premium of $4-5 \%$, which drops to $2 \%$ after controlling for selectivity. The cohabitation premium is found to be of the same size as the marital wage premium. Our results indicate that a part of the marriage or cohabitation premium is not due to marriage or cohabitation itself, but to fatherhood. When information on becoming a father and years spent in fatherhood is added to the empirical model, the results show that fathers receive a 'fatherhood' premium during their first few years as fathers and that the initial marital wage premium is reduced.

JEL Classification: J12, J31

Keywords: marriage premium, cohabitation, fatherhood

Corresponding author:

Nina Smith

Aarhus School of Business

Department of Economics

Prismet, Silkeborgvej 2

DK 8000 Aarhus C

Denmark

Email:nina@asb.dk

\footnotetext{
* We are grateful to Mette Kornvig and Astrid Würtz for very helpful research assistance.
} 


\section{Introduction}

The word for 'married' in Danish is the same as the word for 'poison'. The word for 'sweetheart' in Danish is the same as the word for 'tax'. In this paper we expand upon the literature documenting a significant marital wage premium for men in the United States to see if a similar differential exists for married men in Denmark - or if the homonyms have perhaps less of a double meaning.

The existence of a male marital wage premium has been well documented in the US. There are two primary theoretical explanations for this differential. One explanation is that more productive men are selected into marriage, also known as the selection effect. The second is that marriage makes men more productive in the labour force, perhaps because they have more time and/or energy post-marriage to devote to the job or to invest in job-related human capital as a result of intrahousehold specialization. This is called the productivity effect. There is evidence to broadly support each of these explanations in the US, but the precise nature of the selection effect and the productivity effect remains elusive. In this paper, we analyse these effects based on a large panel sample with complete relationship histories consisting of about 35,000 Danish young men, selected from a random 10\% sample of the Danish population constructed from administrative registers for the years $1984-2001$. This long and comprehensive panel data set allows us to more cleanly identify the wage effects of marriage behaviour, intrahousehold specialization, and childbearing compared to previous studies. Further, since there are substantial cross-country differences in marriage or cohabitation behavior, the results from Denmark can be useful for shedding further light on the nature of the male marital wage differential. For example, the wide prevalence of cohabitation in Denmark allows us to identify these effects separately from marriage effects. Finally, we bring to this literature a new hypothesis that 'fatherhood' and not the relationship itself may be the source of the wage gains of married/cohabiting men.

Marriage behaviour is quite different in Denmark as compared to the US. Men marry later in Denmark than in the US. While $21.2 \%$ of US men aged 20-24 in 2000 reported having been married, the comparable figure for Danish men is only $3.4 \%$ or one-sixth as many. Looking at men aged 25-29, 50.8\% in the US have been married compared to $19.0 \%$ in Denmark. The figures converge as men age, so that for the $30-34$ year age group $70.4 \%$ of US men report having been married as compared with $68.1 \%$ of Danish men. One explanation for the later marriage in Denmark is the greater prevalence of cohabitation in Denmark. While couples in the US typically cohabit for only a short spell, and often do so as a prelude to marriage or following a divorce (Forste 2001), cohabitation is a much more 
common and enduring relationship in Denmark. In 2001, 22\% of all couple households in Denmark were cohabiting, as compared with only about 6\% in the US (Fields and Casper (2001). These significantly different cross-country behavioural trends may affect the observed marital wage premium for men. Specifically, marriage may be a more selective state in Denmark, implying a potentially larger selection component of the marital wage differential.

In a closely related point, cohabitation is a common enough relationship in Denmark so that estimates of a cohabitation effect can also be obtained. There may be selection into cohabitation, just as there is selection into marriage. The formally looser relationship implied by cohabitation may, however, have associated with it a weaker selection effect than that associated with marriage (see Bumpass, Sweet, and Cherlin 1991, for evidence of greater uncertainty and Schoen and Weinick 1993, for evidence that marriage and cohabitation partners are chosen differently). Given the lower cost associated with terminating a cohabiting relationship, the degree of specialization within cohabiting households may also be less than that observed within marriages. This is particularly likely if there is any cost associated with specialization. To the extent that the marital wage differential is the result of a productivity change associated with intrahousehold specialization, the productivity change associated with cohabiting relationships could be smaller than the productivity change associated with marriage if the degree of specialization is greater within married households.

Third, there is evidence that the degree of specialization even in married households may be lower in Denmark than in the US. The labour force participation rate of women in Denmark increased very rapidly in the 1960s and 1970s. By the 1990s, Denmark (joint with Sweden) had the highest female labour force participation rate in the OECD (see Jaumotte, 2003). Further, young cohorts of women entering the labour market during the 1980s and 1990s were typically working full-time, not part-time like earlier generations. Recent evidence shows that Danish women do not reduce their labor supply significantly when they become mothers, except for the period on maternal leave, unlike women in most other countries (Smith et al. 2003). By way of contrast, the labour force participation rate for married women in the US with children less than age 3 was only $58.0 \%$ in 2002, while it was 80.5\% for married women with children age 14-17 (Table 598 of 2003 Statistical Abstract of the United States). One reason why Danish households appear to engage in less labor market/non-labor market specialization is that the large Danish public sector has taken over a large part of the care work for children, the sick and the elderly. International comparisons 
based on time use surveys also show that Danes (jointly with Swedes) are less likely to specialize in household production activities (Bonke and Koch-Weser 2004).

In Table 1, the development in the US and Danish gender distribution of housework is shown. In 1965 there appeared to be more specialization within Danish households where men contributed only ten percent as much time towards housework as women as compared to the US where men contributed about thirty percent. In both countries, the gender division of household labour has become more equal over time, suggesting reduced specialization. But this change has been more dramatic in Denmark. By 1985, intrahousehold specialization, as measured by the ratio of male to female housework hours, was equal between Denmark and the US. By 2003, Danish households appear to be less specialized than US households. Furthermore, these changes have entailed much more significant behavioural changes on the part of Danish men. While men in the US in 1985 and 2003 report spending on average the same amount of time on housework; men in Denmark increased their housework time by $50 \%$. With less intrahousehold specialization, Danish men may experience a smaller increase in productivity following marriage than American men. ${ }^{1}$

(Table 1 about here)

Finally, while there is little evidence that fatherhood influences wages in the US, it may be the case that becoming a father is a more significant turning point in the lives of Danish men than either marriage or cohabitation. One hypothesis might be that specialization within the household really starts or changes when the spouse (mother) enters her first maternal leave period following child birth. While any maternity leave available in the US is so short lived that it would make little sense to reallocate household tasks, in Denmark there is an almost $100 \%$ coverage of publicly funded maternal leave, which since 1984 has had a duration of 26 weeks and since 2002, a duration of one year. This leave introduces a major 'shock' to the intrahousehold specialization process in Danish families. Whether this 'shock' introduces a temporary or a permanent change in behaviour remains to be seen, but, fatherhood rather than relationship type may be more closely linked with wage changes in Denmark.

\footnotetext{
${ }^{1}$ One explanation for this observed difference in time allocation between Danish and U.S. men may be the large difference in tax pressure between the two countries. The overall tax pressure in Denmark has increased during the latest decades to a level of about $50 \%$ while the U.S. level is about $30 \%$. Schettkatt (2003) shows that a considerable part of the difference between time allocation in the U.S. and Germany can be explained by the tax wedge in the two countries. Since the tax wedge is larger in Denmark compared to Germany, this result is expect to carry over to Denmark.
} 
Thus, the research questions we address in this study are as follows: Is there a marital wage premium for men from the youngest birth cohorts in the Danish labour market - or has this premium been taxed away because of the changing roles of men and women in the home and the marketplace? Do legally married men get a higher premium - if any - than cohabiting men? Are these premia permanent or temporary? Does the birth of the first child and entry into fatherhood affect men's role as potential breadwinner and thereby cause the behaviour and wages of young men to change, after controlling for potential marital or cohabitation wage premia? If a change does occur, is it temporary or permanent?

The study is based on a large panel sample of about 35,000 Danish men who are first observed at the age of 18 and followed for between 15 and 25 years (from 1984 through 2001). Virtually none of these men are married or cohabiting prior to entering this sample. Thus we are able to observe each individual's complete marriage and cohabitation history. Raw statistics indicate that married men earn $13 \%$ more and cohabiting men $4 \%$ more than men not currently in a relationship. After controlling for observables and selectivity effects, we find that both cohabiting and legally married men receive a small positive and significant 'relationship wage premium' of about $2 \%$ compared to single men. The cohabitation premium is about the same size as the marital wage premium and both premia seem to decline with the duration of the relationship, rather than rise as would be suggested by a specialization/productivity effect. Further, our results indicate that a part of the marriage or cohabitation premium is not due to marriage or cohabitation in itself. When adding information on parental status and years spent as a father, our results show that fathers receive a 'fatherhood' premium during their first few years as fathers. When controlling for fatherhood variables, the initial relationship wage premium is reduced, particularly for legally married men. Furthermore, the premium persists even if the relationship does not. Only in the case of divorce does the premium decline. Since we control for (time constant) selection effects by estimating fixed effects models, we explain this finding as evidence that fatherhood makes men more responsible and productive at their jobs, but the effect is only temporary.

\section{Literature Review}

The observation that married men earn more than men who have never married is not in itself surprising. Married men are typically older than never married men and older men have more experience, hence higher earnings than their younger counterparts. Yet there also exists substantial evidence (see Ribar 2004 for a brief review of the U.S. literature; Schoeni 1995 for general information on several developed countries; Bardasi and Taylor 2004 for 
more detailed information on Great Britain; and Richardson 2003 for information on Sweden), that married men earn more than never married men with the same level of education and experience. This fact can be explained in a number of ways.

Men who marry may be more productive than men who do not marry throughout their lives. This greater productivity makes them better providers and hence better marriage partners. A number of researchers have explored this possibility either by simultaneously modeling both the decision to marry and wages (Nakosteen and Zimmer 1987, Chun and Lee 2001, Ahituv and Lerman 2003) or by using panel data on wages to estimate fixed effects models that control for such individual specific fixed factors as this unobserved productivity differential (Korenman and Neumark 1991, Daniel 1991, Jacobsen and Rayack 1996, Cornwell and Rupert 1997, Gray 1997, Hersch and Stratton 2000, Ginther and Zavodny 2001, Stratton 2002, Richardson 2003, Bardasi and Taylor 2004, Rodgers and Stratton 2004) $)^{2}$. Results indicate that there are differences between men who marry and men who do not. Korenman and Neumark (1991) conclude that $20 \%$ of the marital wage differential is attributable to individual specific and time invariant factors. Gray (1997) reports similar results using a cohort of men born in 1942-1952, but finds that for younger cohorts in the US (born 1958-1965), 100\% of the estimated marital differential is attributable to fixed effects. Rodgers and Stratton (2004) using this younger cohort find that these individual specific differences are not attributable to ability differences as measured by IQ test scores, raising some doubts about the nature of this individual specific effect.

The idea that marriage may change a man's productivity has also received some attention in the literature. One theoretical explanation is drawn from Becker (1991) and based on the fact that individuals in joint households are more able to specialize than those in single person households. Men have historically specialized more in the market sector and women more in the home sector. This leaves men more time and/or energy to spend on their market work. If this translates to higher productivity on the job, then their earnings should immediately rise. Alternatively, men who marry may specialize by increasing their investment in job-related human capital. In this case, their wages may not rise immediately, but will rise more rapidly over time. Several researchers have explored this possibility, some finding evidence that wages do rise more rapidly for married than for unmarried men even after controlling for fixed effects (Korenman and Neumark 1991, Daniel 1991, Gray 1997 for older U.S. cohort born 1942-1952, Stratton 2002), some reporting both a jump and faster

2 Isacsson (2004) employs longitudinal twin data from Sweden to examine the male marriage wage premium. 
wage growth (Daniel 1991, Hersch and Stratton 2000), and some finding that the wage growth effects appear only in cross-section estimates (Cornwell and Rupert 1997, Gray 1997 for the younger U.S. cohort born 1958-1965, Rodgers and Stratton 2004) or not at all (Richardson 2003, Bardasi and Taylor 2004).

There are a number of problems with both the evidence and the theory behind the marital wage differential. One concern with the selection hypothesis is that virtually all men eventually marry. In the United States, $63 \%$ of all white, non-Hispanic women are married by age 25, 81\% by age 30 (Bramlett and Mosher 2002). Those who never marry are but a small and likely unusual fraction of the population. Studies using data on persons of all ages are unlikely to observe many first time marriages. Estimates based on limited cohorts (typically of young persons), have a better chance of including more first time marriages, but even the 'youth cohorts' include a substantial fraction of men who are married when first observed (78\% in Korenman and Neumark's seminal work (1991), 76.2\% in Gray (1997), 66.2\% in Hersch and Stratton (2000)). In general, estimates of the marital wage differential rely a great deal not on first marriages but on separation/divorce and remarriage for identification of the marital wage premium (see Cornwell and Rupert (1997) for a further discussion of this). While most studies assume the impact of getting married is symmetric to the impact of a marriage's end, this may not be the case. It may also be the case that controls for years married actually capture the impact of the timing of marriage. If those who marry younger are different from those who marry later - then specifications that control for years married may in fact be capturing a proxy for age at marriage rather than controlling for differential rates of wage growth following marriage, substantially changing the interpretation of these coefficients.

In addition, much of the literature ignores cohabitation. Exceptions include Schoeni (1995) who finds no effect of cohabitation on earnings in Germany; Loh (1996), Stratton (2002), and Bardasi and Taylor (2004) who conclude that any effect of cohabitation is transitory; and Cohen (2002) and Richardson (2003) who find cohabiting men receive a smaller premium than married men. Stratton (2002) has both panel data and cohabitation histories, though the panel consists of only two data points and the cohabitation histories are incomplete. Controlling for individual specific effects, she finds that the marital wage premium is significantly positive, but the cohabitation premium becomes insignificant. Given the decline in marriage and the increase in cohabitation rates over the last 30 years (Bumpass, Sweet, and Cherlin 1991), further attention is due this distinction. 
When the analysis has focused on young persons more likely to enter marriage for the first time, another problem arises. Typically such samples are restricted to persons who have completed their education and are employed. The latter restriction is, of course, necessary in order to study wages. However, the decision to marry and the decision to enroll in school or take a job are likely endogenous. Thus, while data consisting of young men should in theory follow individuals as they marry for the first time, this is generally not the case (as discussed above) because by the time they are observed out of school and employed, a significant fraction are already married. ${ }^{3}$ Essentially this is a sample selection problem.

\section{Data}

In this study, we use a large panel sample of young Danish men to address several of these shortcomings, while bringing new Danish evidence on the marital wage differential taking marital and cohabitation histories into consideration. ${ }^{4}$ Our initial sample consists of a 10\% sample of the Danish born population of men born between 1966 and 1975 inclusive - a total of 37,881 men aged 18 or less in 1984. Register data on these individuals is available annually from 1984 till 2001 - yielding 564,788 observations on men age 16-35. As fewer than $0.2 \%$ of Danish men are married by age 18 (according to Statistics Denmark (2000)), virtually no men enter our sample married. Only $2 \%$ are cohabiting at the time of entry. Thus, we are able to achieve cleaner identification of the marriage and cohabitation wage differential compared to previous studies that have identified these effects mainly off of relationship dissolution.

Marriage histories are obtained directly from official administrative records. The register reports precise dates of marriage and divorce, including also annual information on whether the marriage partner or another partner of the opposite sex (and within 15 years of age) is present in the household. This allows us to estimate both the time of separation and the time spent cohabiting. Studies typically treat separated and divorced couples similarly, as specialization is contingent on having a partner in residence. While the register data are certainly far more accurate than the survey data typically used in these types of analyses, they

\footnotetext{
${ }^{3}$ As an example, in the sample applied in this study (a random sample of young Danish men), for the age cohort aged 25 years in year 2000, 24\% were still students, i.e. under education. Among these students, 41\% were either married or cohabiting.

${ }^{4}$ A paper on the gender wage differential in Denmark (Naur and Smith 1997) provides some evidence that there is a Danish male marriage premium of approximately four percent. This differential is smaller in part because of the smaller overall wage dispersion in Denmark as compared to the U.S.. Naur and Smith differentiate between married and cohabiting men and find no evidence of a cohabiting wage differential. They do not, however, control for time married or cohabiting.
} 
are not perfect. Because co-residence information is only available annually, cohabiting relationships that last only a short while will be undersampled. Such relationships are, however, unlikely to have any substantial influence on earnings, so the loss is relatively minor. In addition, as individuals are not directly asked the nature of their relationship with nonmarital partners, roommates may be incorrectly classified as cohabitors, and individuals who have substantially older partners or cohabiting partners who maintain a separate legal address may be incorrectly classified as single persons. Comparison of register and survey data from another Danish source (the 2001 Danish Time Use Survey) suggests that more cohabiting persons will be misclassified as single than vice versa. Any such errors are likely to lead the effect of cohabitation (and possibly marriage) on wages to be underestimated as the base group against which all are compared is contaminated.

As the data allow distinguishing between different partners, we can observe partner changes and identify cohabitors who go on to marry. As we observe individuals from a very young age, we are able to construct a very comprehensive relationship history for every respondent. This is in contrast to Richardson (2003) who has information only on the duration of the current marriage, no complete marital history, and no information on how long any cohabiting couple has been together, and to Stratton (2002) who has only incomplete cohabitation records. Having complete histories is particularly important in Scandinavia where cohabitation is very common. ${ }^{5}$ Restricting the sample to those not missing information on marital status or history, to those not presently widowed, to those never observed in a gay union, and to those who are not fathers when first observed, reducing our sample size slightly to 548,054 observations on 37,802 individuals.

Employment data are also obtained from the Danish register. These are the official records that report earnings, education, job experience, occupation, and industry. ${ }^{6}$ In order to keep as complete a sample as possible, we do not restrict our wage analysis to those who have completed their education. At the age of $25,18 \%$ of the individuals in our sample are still enrolled, see Table 3. However, in order to analyse wages we must restrict our analysis to individuals for whom we have information on education, occupation, industry, and labour market experience; who have wage reports of between 40 and 800 Danish kroner per hour

\footnotetext{
${ }^{5} 22 \%$ of all couples in Denmark, incl. all age categories, were cohabiting couples in 2001 according to Statistics Denmark (2001). Younger people have much higher cohabiting rates than the rest of the adult population. In the sample used in this study which includes young men aged 18-35 years, there are twice as many observations on cohabiting individuals as there are on legally married individuals.

${ }^{6}$ The definition of occupational categories changes in 1996 so that the same categories cannot be identified during the whole period. Therefore, we use two sets of occupational categories, one for the years before 1996 and one for the years after.
} 
(between 7 and 133 US-dollars); who worked more than 20\% of the year (about 320 hours); and who are not self-employed. ${ }^{7}$ Further, all individuals who are only observed once are excluded as they contribute nothing to panel estimates. This leaves us with a primary sample of 297,938 observations on 33,798 individuals. Nonemployment accounts for almost half of the observations lost at this stage; lack of a reasonable wage measure accounts for another quarter, and the rest are dropped because they are only observed once. In order to more nearly match restrictions imposed in the US based literature, a second sample that excludes those who have not completed their education and those who worked less than $80 \%$ of the year (about 1280 hours) is constructed. This sample contains 172,883 observations on 24,951 individuals.

Sample statistics for selected variables in the larger sample of 33,798 individuals are reported in Table 2 for both the 2001 cross-section and the pooled panel data set covering the period 1984 - 2001. In the appendix, sample statistics for all variables included in the analysis are shown. According to Table 2, as of 2001, 34\% of the 25,548 men in the sample were married, 34\% were cohabiting, and among those men not observed in a relationship 37\% had previously been cohabiting and $8 \%$ had previously been married. Thus, even for the last year of the panel, cohabitation is clearly more widespread than legal marriage. In 2001, married men earned on average 127 DKK hourly, compared to only 117 DKK and 112 DKK for cohabiting and single men. These raw statistics indicate that married men earned $13 \%$ more and cohabiting men $4 \%$ more than men not currently in a relationship. Part of this raw marital wage differential is obviously attributable to the fact that the married men were on average close to 2 years older than the non-married men.

(Table 2 and Table 3 about here)

Table 3 presents statistics pertaining to changing marital status, to fatherhood, and to educational enrollment status. At the age of 18, almost none of the 33,798 individuals who are included in this study were married $(0 \%)$, cohabiting (2\%) or had had their first child, while at the age of 35, 53\% were legally married and 24\% were cohabiting, and 66\% had become fathers. $51 \%$ were enrolled in school at the age of 18 , while almost all individuals

\footnotetext{
${ }^{7}$ We have no information on hourly wages for self-employed workers. The 320 hours' restriction excludes the majority of temporary holiday jobs, for which wage information may be unreliable.
} 
had left the educational system by the age of $35 .{ }^{8}$ Since we restrict our sample to individuals, with 'reliable' wage information who were employed for at least $20 \%$ of the year, Table 3 is not representative of all young Danish men. A substantial number of full-time students who do not have a job are excluded.

\section{Analysis}

The analysis is based on the estimation of a traditional human capital wage function

$$
\ln \mathrm{W}_{\mathrm{it}}=\beta_{\mathrm{t}}+\mathbf{X}_{\mathrm{it}} \boldsymbol{\beta}+\mathbf{Z}_{\mathrm{it}} \boldsymbol{\gamma}+\left(\alpha_{\mathrm{i}}+\varepsilon_{\mathrm{it}}\right) \text {. }
$$

where $\mathbf{X}_{\mathrm{it}}$ is a vector of explanatory variables: occupational category and sector of employment; region of residence; experience, experience squared, and educational level; and $\mathbf{Z}_{\text {it }}$ is a vector of family status variables (indicators for marriage, cohabitation, divorce/separation, and past cohabitation; quadratic duration measures for these states; and variables reflecting the age and presence of children and of fatherhood). The subscripts $i$ and $t$ index the individual and time, respectively. $\alpha_{\mathrm{i}}$ is the unobserved heterogeneity term, assumed to be individual-specific, time-invariant, and $\varepsilon_{\mathrm{it}}$ is an error component, $\operatorname{Nid}\left(0, \sigma_{\varepsilon}^{2}\right)$.

We begin by replicating the standard marital wage equations where only information on marriage and divorce is entered in the wage function. Table 4, columns 1 and 2 show pooled OLS and fixed effects estimates for the sample of young Danes working full-time who have completed school (Sample 1). A small but significant marriage premium of about $2 \%$ is found in the pooled OLS regressions, but when controlling for unobserved individual effects, i.e. selectivity into marriage, the marital wage premium seems to disappear. For those individuals who divorce, wages are significantly lower than for those individuals who have never been legally married. These results indicate a much lower marital wage premium than typically found in U.S. studies, as described above.

(Table 4 about here)

However, these findings are in part due to the specification of the model. In columns 1-2 the excluded category contains both single and cohabiting men. In columns 3 and 4, we

\footnotetext{
${ }^{8}$ We assume that individuals who are observed not enrolled at the age of 26 have completed their education. This assumption is necessary because the youngest men in our sample are aged 26 when last observed in 2001. A small number of observations reenroll after the age of 26 . Thus, we may incorrectly classify some individuals as having completed their education, although they later become re-enrolled.
} 
merge the categories of married and cohabiting men, comparing all partnered men to singles. This changes the estimated selection corrected relationship wage premium, which becomes significantly positive - though small, about $1 \%$ for both married/cohabiting men, divorced men, and men who have cohabited in the past. Finally, columns 5-6 show the estimated coefficients from a specification in which marriage and cohabitation are treated as distinct relationships. As found in Stratton (2002), the cohabitation premium is smaller than the marriage premium (p-values for a test of equality are 0.000 in both specifications). Pooled OLS estimates show premia of about 3-4\%, but the selectivity corrected premia are much smaller, i.e. selectivity effects are quite important for this group of young men working fulltime. According to the estimates, selectivity effects account for between half and two thirds of the observed marital wage premium.

Sample 1 is a sample of young men working full-time who have left the educational system, either without a formal education or with a completed education. As a large number of Danish men in the age group 20-30 years are still enrolled in school, this selection mechanism tends to oversample low-skilled, uneducated men. Though we control for education and occupation, the estimated marriage premia found in columns 1-6 may be misleading because of potential unobserved (time varying) factors. ${ }^{9}$ In columns 7-12 the same models are estimated using a sample of all young men for whom we observe reliable wage information (Sample 2). This sample includes students who work while enrolled in school, a situation which is very common among Danish students as described in Table $3 .^{10}$ Extending the sample clearly has a positive effect on the estimated wage premium from marriage and cohabitation in all specifications. According to column 12, the marriage and cohabitation premia are both $1.6 \%$, indicating that married and cohabiting men earn the same marital wage premium - as long as they stay with their partners! If they separate, those who were cohabiting in the past earn about the same premium while those who were legally married do not have higher wages than singles.

The accumulated experience in jobs as students may have a different effect on wages than experience accumulated in jobs after completing the latest obtained education. If some

\footnotetext{
${ }^{9}$ As an alternative, we might have modeled the selection into Sample 1 explicitly. However, it is difficult to identify this selection because we have to find variables which affect the educational decision but do not affect wage level. Therefore we prefer to include all observations but use a flexible wage specification which allows the experience profile to change when education is completed.

${ }^{10}$ We do not include an indicator for part time work in the estimations shown because part time work in Denmark is typically paid according to the same pay scales as full time work. So, controlling for education and occupation, part time work is not found to have a negative effect on hourly wage rates, see for instance Datta Gupta and Smith (2002).
} 
types of men tend to marry after completing their education, we may mix the effects from marriage and cohabitation with effects from differential wage growth following completion of school and education. Therefore to allow the model to be more flexible with respect to the effect of experience, we split the experience variable into experience accumulated before the highest observed level of education was completed and experience accumulated after completing education. Selected coefficients from this estimation are shown in Table 5. As expected, the wage effect of accumulated experience from 'student jobs' is smaller than the wage effect of experience accumulated after completing education. The more flexible specification of the wage function matters for the relative size of the estimated wage premium for legally married and cohabiting men. The premium decreases from $1.6 \%$ to $1.4 \%$ for legally married men, while it increases from $1.6 \%$ to $2.0 \%$ for cohabiting men. For those who divorce and for cohabiting couples that split, the difference between a legal marriage and cohabitation seems even more pronounced. Men who divorce earn $1 \%$ less than singles, while men who were formerly cohabiting earn $2 \%$ more than singles. Since we control for potential selectivity effects, this may be explained by a loss for legally married of the gains from household specialization.

\section{(Table 5 about here)}

Many studies have documented that the marriage premium may change over time. If specialization is important, i.e. if spouses specialize in market work (men) or home production (women), we should expect an increasing wage premium profile. US studies often find a positive differential premium which increases with years married, at a decreasing rate, while for Scandinavia, Richardson (2003) finds a negatively sloped profile, i.e. marriage only tends to have a short run effect. In Table 6, we extend the preferred flexible wage model that includes separate pre and post education experience measures with measures of the duration of different marital and cohabitation states (column 2), and additionally, their square terms (column 3). When including a linear measure of the duration of marriage and cohabitation, column 2 shows that for young Danish men, the specialization hypothesis does not seem to hold. There is a short term positive effect of marriage and cohabitation, but it disappears after 5-10 years, faster for married as compared to cohabiting men. At the same time, the negative total effect of divorce on earnings seems to be driven by lower wage growth for divorced men. Indeed all men not observed in a relationship appear to have significantly lower wage growth. Extending the models with squared duration terms, indicates that the duration 
measures do not affect the marital wage premium in a linear way (p-value of test for significance of quadratic measures is 0.0002 ).

(Table 6 about here)

The results above give evidence of a small marital wage premium in Denmark for young men observed during their first period in the labour market and their first marriage and/or cohabitation relationships. Our results indicate a much smaller premium than found in U.S. studies or in Sweden where Richardsson (2003) found a marital wage premium of 8.5\% and a cohabitation premium of about half the marital wage premium. One reason may be that we analyse much younger birth cohorts of men than Richardsson (and most U.S. studies) and for these cohorts, the changing role of women and families (less specialization and more market work for women) is much more pronounced than in older birth cohorts.

To extend this hypothesis one step further, we finally analyse whether the small observed marital and cohabitation wage premium of about $1.5-2 \%$ is really a premium to having a partner, or whether it may instead reflect a child birth related premium captured because of the relation between marriage/cohabitation and child birth. In table 7 column 2, we include an additional variable to identify households with children aged 0-17 years old. For simplicity, we have dropped the quadratic duration measures. Apparently the presence of a child has no significant effect on the estimated relationship wage premium. When adding more detailed information on the age of the children, we find that it is only young children who significantly affect the wages of their fathers. When the child turns 3 or more, the positive initial effect is turned into a significant negative effect! Furthermore, the effect of marriage and cohabitation seems to decrease slightly, when controlling for the presence of children in different age categories.

(Table 7 about here)

Therefore we include, parallel to the marriage variables, a variable measuring the duration of fatherhood. The inclusion of the variable measuring duration of fatherhood reduces the estimated relationship premium further, especially for legally married men. But the estimated initial effect does not decrease over time or even with the end of the relationship (though the growth rate of wages is less for divorced men not in a relationship), when controlling for fatherhood. There seems to be a positive initial effect of having a child, 
but the effect disappears within a matter of years. This result may indicate that fatherhood makes men more responsible and productive at their job, but the effect is only temporary.

\section{Conclusion}

In this study, we find that between half and two-thirds of the marital wage differential in Denmark is attributable to a selection effect. At first glance, this effect seems to be larger than that found in most US studies, but marriage is a more selected state in Denmark, and further, ours is a recent cohort and US studies using recent cohorts have found large selection effects as well. Our results show that it is important to take cohabitation explicitly into account when estimating the marital wage differential. Cohabiting or legally married men obtain a small positive and significant 'marital wage premium' of about $2 \%$ compared to single men. The cohabitation premium is about the same size as the marital wage premium in Denmark, contrary to most other studies from the US and contrary to expectations. This suggests that selection into cohabitation is fairly similar to selection into marriage, even though statistical tests reject the hypothesis that marriage and cohabitation have an identical effect on earnings. When controlling for children and fatherhood, the relationship premium seems to be a short run effect which disappears after about 5 years for married men and 10 years for cohabiting men. Thus, we do not find evidence of faster wage growth for men in a relationship, which could signal household specialization effects on men's wages. This may reflect the fact that the distribution of housework is fairly equal in young Danish couples, as indicated by recent time use studies.

Further, our results indicate that a part of the marriage or cohabitation premium is not due to marriage or cohabitation itself. When adding information on becoming fathers and years spent in fatherhood, our results show that fathers receive a 'fatherhood' premium during their first few years as fathers, contrary to what has been found for the US. When controlling for fatherhood variables, the initial marital wage premium is reduced, but the effect seems to be permanent, contrary to the models which do not control for fatherhood. Men who divorce also lose their initial marriage premium a few years after divorce, compared to those who stay married. Only men who stay married earn a permanent marital premium. Since we control for (time constant) selection effects by estimating fixed effects models, we explain the jump in wages and their declining growth rate following childbirth as evidence that fatherhood makes men more responsible and productive on the job, but the effect is temporary, perhaps induced by temporary changes in household duties brought about by the 26 week leave most Danish women take following child birth. 
Thus, marriage is not 'poisonous' in Denmark, but the premium paid to married men is low and part of it may have been 'taxed' away as the roles within the household have changed and reduced intrahousehold specialization. 


\section{Bibliography}

Ahituv, Avner and Robert Lerman. 2003. “Job Stability, Earnings, Marital Stability: How are They Related?” Mimeo.

Bardasi, Elena and Mark Taylor. 2004. "Investigating the Marriage Wage Premium for Men in Britain.” Paper presented at ESPE meetings Bergen, Norway.

Becker, Gary S. 1991. A Treatise on the Family. Enl. Ed. Cambridge, Mass.: Harvard University Press.

Bonke, Jens and Elke Koch-Weser. 2004. The Welfare State and Time Allocation in Sweden, Denmark, France and Italy, in Janet Zollinger Giele and Elke Holst (eds.),

“Changing life patterns in Western Industrial Societies”. Elsevier, JAI, 2004

Bramlett, Matthew D. and William D. Mosher. 2002. Cohabitation, Marriage, Divorce, and Remarriage in the United States. National Center for Health Statistics. Vital Health Stat 23(22).

Bumpass, Larry L., James A. Sweet, and Andrew Cherlin. 1991. "The Role of Cohabitation in Declining Rates of Marriage.” Journal of Marriage and the Family, 53, No. 4 (November), pp. 913-927.

Chun, Hyunbae and Injae Lee. 2001. "Why Do Married Men Earn More: Productivity or Marriage Selection?” Economic Inquiry, Vol. 39, No. 2 (April), pp. 307-319.

Cohen, Philip N. 2002. “Cohabitation and Declining Marriage Premium for Men.” Work and Occupations, Vol. 29, No. 3 (August), pp. 346-363.

Cornwell, Christopher and Peter Rupert. 1997. "Unobserved Individual Effects, Marriage, and the Earnings of Young Men.” Economic Inquiry, Vol. 35, No. 2 (April), pp. 285-94.

Daniel, Kermit. 1991. “Does Marriage Make Men More Productive?” Unpublished paper, University of Chicago.

Datta Gupta, Nabanita and Nina Smith. (2002). “Children and Career Interruptions: The Family Gap in Denmark.” IZA discussion paper \#263. Economica, 69 (276), pp. 609629.

Fields, Jason and Lynne Casper (2001). “America’s Families and Living Arrangements: March 2000”. Current Population Reports, P20-537, U.S. Census Bureau, Washington DC.

Forste, Renata. 2001. "Prelude to Marriage or Alternative to Marriage? A Social Demographic Look at Cohabitation in the U.S.” Manuscript prepared for the Symposium on the ALI’s Family Dissolution Principles. Brigham Young University. 
Ginther, Donna and Madeline Zavodny. 2001. "Is the Male Marriage Premium Due to Selection? The Effect of Shotgun Weddings on the Return to Marriage.” Journal of Population Economics, 14, pp. 313-328.

Gray, Jeffrey S. 1997. “The Fall in Men’s Return to Marriage: Declining Productivity Effects or Changing Selection?” Journal of Human Resources, Vol. 32, No. 3 (Summer), pp. 481-504.

Hersch, Joni and Leslie S. Stratton. 2000. "Household Specialization and the Male Marriage Wage Premium.” Industrial and Labor Relations Review, Vol. 54, No. 1 (October), pp. 78-94.

Isacsson, Gunnar. 2004. "Estimating the economic return to educational levels using data on twins”, Journal of Applied Econometrics, Vol. 19, issue 1, pp. 99-119.

Jacobsen, Joyce P. and Wendy L. Rayack. 1996. “Do Men Whose Wives Work Really Earn Less?”. American Economic Review, Vol. 86, No. 2 (Papers and Proceedings May), pp. 268-273.

Jaumotte, Florence. 2003. "Female labour force participation: past trends and main determinants in OECD countries”, OECD Economics Department Working Papers, No. 376.

Korenman, Sanders and David Neumark. 1991. “Does Marriage Really Make Men More Productive?” Journal of Human Resources, Vol. 26, No. 2 (Spring), pp. 282-307.

Lausten, Mette and Karen Sjørup. 2003. "How do men and women spend their time?” (In Danish), The Danish National Social Research Institute, 03:08, Copenhagen.

Loh, Eng Seng. 1996. "Productivity Differences and the Marriage Wage Premium for White Males.” Journal of Human Resources, Vol. 31, No. 3 (Summer), pp. 566-89.

Nakosteen, Robert A. and Michael A. Zimmer. 1987. "Marital Status and Earnings of Young Men.” Journal of Human Resources, Vol. 22, No. 2 (Spring), pp. 248-68.

Naur, Michèle and Nina Smith. 1997. "Cohort Effects on the Gender Wage Gap in Denmark.”, in Inga Persson and Christina Jonung (eds.), 'Women’s Work and Wages, Routledge, vol 2, 122-144.

Ribar, David. 2004. "What Do Social Scientists Know about the Benefits of Marriage? A Review of Quantitative Methodologies.” IZA Discussion Paper No. 998.

Richardson, Katarina. 2003. "The Evolution of the Marriage Premium in the Swedish Labor Market 1968-1991.” Mimeo.

Rodgers, William M. III and Leslie S. Stratton. 2004. “The Male Marital Wage Differential: Race, Ability, and Training.” Mimeo. 
Schettkat R.. 2003. "Differences in US-German Time-Allocation: Why Do Americans Work Longer Hours than Germans?” IZA Discussion Paper no. 697, IZA, Bonn.

Schoen, Robert and Robin M. Weinick. "Partner Choice in Marriages and

Cohabitations." Journal of Marriage and the Family, 55, 2 (May 1993), pp. 408-414.

Schoeni, Robert F. 1995. "Marital Status and Earnings in Developed Countries.”

Journal of Population Economics, Vol. 8, pp. 351-359.

Smith; Nina, Shirley Dex, Tim Callan and Jan D. Vlasblom. 2003. "Taxation of

Spouses: A Cross Country Study of the Effects on Married Women’s Labour Supply.”

Oxford Economic papers, 55 (3), 417-439.

Statistical Abstract of the United States 2003. http://www.census.gov/prod/2004pubs/

03statab/labor.pdf.

Statistics Denmark. 2000. Statistical Yearbook (1999), Copenhagen.

Stratton, Leslie S. 2002. "Examining the Wage Differential for Married and

Cohabiting Men.” Economic Inquiry, Vol. 40, No. 2 (April), pp. 199-212. 
Table 1. Average weekly hours spent on housework. Men and women in Denmark and the U.S. ${ }^{1)}$

\begin{tabular}{llllll}
\hline & & 1965 & 1975 & 1985 & 2003 \\
\hline Denmark & Men & 3 & 8 & 11 & 17 \\
& Women & 31 & 27 & 21 & 24 \\
& Ratio (male/female hours) & 0.10 & 0.30 & 0.52 & 0.71 \\
\hline U.S. & Men & 12 & 14 & 16 & 16 \\
& Women & 40 & 33 & 31 & 28 \\
& Ratio (male/female hours) & 0.30 & 0.42 & 0.52 & 0.57 \\
\hline
\end{tabular}

Note 1: For Denmark, data for the years shown are based on the time use studies collected in 1964, 1975, 1987, and 2001. For both countries, the data from 2001/2003 are based on time use data collected by other institutions or based on slightly different principles and therefore the absolute level may not be comparable to the previous years, see Lausten and Sjørup (2003). However, the ratio of male to female hours is expected to be robust and comparable across years. Age group for Denmark is 16-74 years, for the U.S. 15+.

Source: Denmark, Lausten and Sjørup (2003). U.S., data for 1965, 1975 and 1985 stems from ISR Panel Income Dynamics, see Current Archives, www.umich.edu/news/?Releases/Mar02/chr031202a. Data from 2003 are calculated from the new time use surveys from Bureau of Labor Statistics, News September 2004, www.bls.gov/news.release/atus.txt 
Table 2. Sample Statistics

\begin{tabular}{|c|c|c|c|c|c|}
\hline & \multirow{2}{*}{$\begin{array}{c}\text { All years } \\
\text { All }\end{array}$} & \multicolumn{4}{|c|}{2001} \\
\hline & & All & Married & Cohabiting & $\begin{array}{c}\text { Not in a } \\
\text { Relationship }\end{array}$ \\
\hline Age & 25.344 & 30.698 & 31.900 & 30.071 & 30.081 \\
\hline Hourly Wage Rate, DKK, 1984 prices & 96.392 & 118.620 & 126.624 & 116.804 & 112.060 \\
\hline Married & 0.153 & 0.341 & 1 & 0 & 0 \\
\hline Cohabiting & 0.297 & 0.337 & 0 & 1 & 0 \\
\hline Divorced or separated & 0.009 & 0.025 & 0 & 0 & 0.077 \\
\hline Cohabitated in the past & 0.091 & 0.120 & 0 & 0 & 0.371 \\
\hline Child aged 0-17 years & 0.210 & 0.445 & 0.844 & 0.449 & 0.018 \\
\hline Years married & 0.543 & 1.590 & 4.269 & 0.128 & 0.284 \\
\hline Years cohabiting & 1.661 & 3.349 & 3.972 & 4.795 & 1.184 \\
\hline Years since individual became a father & 1.010 & 2.741 & 4.928 & 2.137 & 1.061 \\
\hline No of observations & 297,938 & 25,548 & 8,707 & 8,598 & 8,243 \\
\hline No of individuals & 33,798 & 25,548 & 8,707 & 8,598 & 8,243 \\
\hline
\end{tabular}


Table 3. Proportion who are married, cohabiting, fathers and who are still under education. The effective sample of 33,798 individuals (incl. students with a part time job).

Proportion of age group who is:

\begin{tabular}{lcccc} 
Age & Married & $\begin{array}{c}\text { Married or } \\
\text { Cohabiting }\end{array}$ & Fathers & $\begin{array}{c}\text { Enrolled - still } \\
\text { in school }\end{array}$ \\
\hline 18 & 0.00 & 0.02 & 0.00 & 0.51 \\
19 & 0.00 & 0.05 & 0.00 & 0.43 \\
20 & 0.00 & 0.11 & 0.01 & 0.36 \\
21 & 0.01 & 0.19 & 0.02 & 0.23 \\
22 & 0.02 & 0.28 & 0.04 & 0.15 \\
23 & 0.03 & 0.36 & 0.06 & 0.13 \\
24 & 0.06 & 0.43 & 0.10 & 0.12 \\
25 & 0.09 & 0.49 & 0.14 & 0.11 \\
26 & 0.13 & 0.55 & 0.19 & 0.10 \\
27 & 0.17 & 0.59 & 0.25 & 0.08 \\
28 & 0.23 & 0.63 & 0.32 & 0.07 \\
29 & 0.29 & 0.66 & 0.39 & 0.05 \\
30 & 0.36 & 0.69 & 0.45 & 0.05 \\
31 & 0.40 & 0.71 & 0.51 & 0.04 \\
32 & 0.43 & 0.72 & 0.55 & 0.03 \\
33 & 0.47 & 0.74 & 0.60 & 0.03 \\
34 & 0.50 & 0.75 & 0.63 & 0.02 \\
35 & 0.53 & 0.77 & 0.66 & 0.02 \\
\hline
\end{tabular}


Table 4. Estimation of male hourly wage function for full time workers, excl. students (Sample 1) and all young people with observed wages (Sample 2). Selected coefficients. Standard deviations in parentheses.

\begin{tabular}{|c|c|c|c|c|c|c|c|c|c|c|c|c|}
\hline & \multicolumn{6}{|c|}{$\begin{array}{c}\text { Sample } 1 \\
\text { Full time workers, excl. Students }{ }^{1)}\end{array}$} & \multicolumn{6}{|c|}{$\begin{array}{c}\text { Sample } 2 \\
\text { All individuals with reliable wage information, incl. } \\
\text { students }^{1), 2)}\end{array}$} \\
\hline & (1) & (2) & (3) & (4) & (5) & (6) & (7) & (8) & (9) & (10) & (11) & (12) \\
\hline & $\begin{array}{l}\text { Pooled } \\
\text { OLS }\end{array}$ & FE & $\begin{array}{l}\text { Pooled } \\
\text { OLS }\end{array}$ & $\mathrm{FE}$ & $\begin{array}{l}\text { Pooled } \\
\text { OLS }\end{array}$ & $\mathrm{FE}$ & $\begin{array}{l}\text { Pooled } \\
\text { OLS }\end{array}$ & FE & $\begin{array}{l}\text { Pooled } \\
\text { OLS }\end{array}$ & $\mathrm{FE}$ & $\begin{array}{l}\text { Pooled } \\
\text { OLS }\end{array}$ & $\mathrm{FE}$ \\
\hline & $\begin{array}{l}0.022 * * * \\
(0.003)\end{array}$ & $\begin{array}{l}0.002 \\
(0.002)\end{array}$ & $0.030 * * *$ & $0.009 * * *$ & $\begin{array}{l}0.041 * * * \\
(0.003)\end{array}$ & $\begin{array}{l}0.012 * * * \\
(0.002)\end{array}$ & $\begin{array}{l}0.023 * * * \\
(0.003)\end{array}$ & $\begin{array}{l}0.001 \\
(0.002)\end{array}$ & $0.037 * * *$ & $0.016^{* * *}$ & $\begin{array}{l}0.047 * * * \\
(0.003)\end{array}$ & $\begin{array}{l}0.016 * * * \\
(0.002)\end{array}$ \\
\hline Cohabiting & - & - & $(0.002)$ & $(0.002)$ & $\begin{array}{l}0.025 * * * \\
(0.002)\end{array}$ & $\begin{array}{l}0.009 * * * \\
(0.002)\end{array}$ & - & - & $(0.002)$ & $(0.002)$ & $\begin{array}{l}0.033 * * * \\
(0.002)\end{array}$ & $\begin{array}{l}0.016 * * * \\
(0.002)\end{array}$ \\
\hline & $\begin{array}{l}-0.000 \\
(0.003)\end{array}$ & $\begin{array}{l}-0.016^{* * *} \\
(0.005)\end{array}$ & $0.029 * * *$ & $0.008 * * *$ & $\begin{array}{l}0.020 * * * \\
(0.007)\end{array}$ & $\begin{array}{l}-0.000 \\
(0.005)\end{array}$ & $\begin{array}{l}0.007 \\
(0.006)\end{array}$ & $\begin{array}{l}-0.025^{* * *} \\
(0.005)\end{array}$ & $0.039 * * *$ & $0.014 * * *$ & $\begin{array}{l}0.031 * * * \\
(0.007)\end{array}$ & $\begin{array}{l}-0.006 \\
(0.005)\end{array}$ \\
\hline $\begin{array}{l}\text { Cohabited in } \\
\text { the past }\end{array}$ & - & - & $(0.003)$ & $(0.002)$ & $\begin{array}{l}0.031^{* * *} \\
(0.003)\end{array}$ & $\begin{array}{l}0.010 * * * \\
(0.003)\end{array}$ & - & - & $(0.003)$ & $(0.002)$ & $\begin{array}{l}0.041^{* * * *} \\
(0.003)\end{array}$ & $\begin{array}{l}0.016 * * * \\
(0.002)\end{array}$ \\
\hline $\begin{array}{l}\text { No of } \\
\text { individuals }\end{array}$ & 24,951 & 24,951 & 24,951 & 24,951 & 24,951 & 24,951 & 33,798 & 33,798 & 33,798 & 33,798 & 33,798 & 33,798 \\
\hline $\begin{array}{l}\text { No of } \\
\text { observations }\end{array}$ & 172,883 & 172,883 & 172,883 & 172,883 & 172,883 & 172,883 & 297,938 & 297,938 & 297,938 & 297,938 & 297,938 & 297,938 \\
\hline $\begin{array}{l}\text { R-square } \\
\text { (FE: overall) }\end{array}$ & 0.327 & 0.262 & 0.328 & 0.262 & 0.329 & 0.263 & 0.452 & 0.404 & 0.453 & 0.405 & 0.453 & 0.405 \\
\hline
\end{tabular}

$* * *, * *$, and * indicates significance at $1 \%, 5 \%$ and $10 \%$ level, respectively.

Note 1: All models include controls for region, educational level, employment experience (and square term), occupational status, sector, and year dummies are included.

Note 2: Total accumulated experience (sum of experience before and after completing education) and experience squared are included as controls. 
Table 5. Estimation of male hourly wage function, fixed effects estimations of models on different samples and with different specification of experience. Selected coefficients. Standard deviations in parentheses.

Sample $1 \quad$ Sample $2 \quad$ Sample 2

\begin{tabular}{|c|c|c|c|}
\hline & $\begin{array}{l}\text { Full time } \\
\text { workers, excl. } \\
\text { Students }\end{array}$ & $\begin{array}{l}\text { All individuals } \\
\text { with reliable } \\
\text { wage information, } \\
\text { incl. students }\end{array}$ & $\begin{array}{l}\text { All individuals with } \\
\text { reliable wage } \\
\text { information, incl. } \\
\text { students }\end{array}$ \\
\hline Married & $\begin{array}{l}0.012 * * * \\
(0.002)\end{array}$ & $\begin{array}{l}0.016^{* * *} \\
(0.002)\end{array}$ & $\begin{array}{l}0.014^{* * *} \\
(0.002)\end{array}$ \\
\hline Cohabiting & $\begin{array}{l}0.009 * * * \\
(0.002)\end{array}$ & $\begin{array}{l}0.016 * * * \\
(0.002)\end{array}$ & $\begin{array}{l}0.020 * * * \\
(0.002)\end{array}$ \\
\hline Divorced & $\begin{array}{l}-0.000 \\
(0.005)\end{array}$ & $\begin{array}{l}-0.006 \\
(0.005)\end{array}$ & $\begin{array}{l}-0.009^{* *} \\
(0.005)\end{array}$ \\
\hline Cohabited in the past & $\begin{array}{l}0.010 * * * \\
(0.003)\end{array}$ & $\begin{array}{l}0.016 * * * \\
(0.002)\end{array}$ & $\begin{array}{l}0.021^{* * *} \\
(0.002)\end{array}$ \\
\hline $\begin{array}{l}\text { Total employment } \\
\text { experience }\end{array}$ & $\begin{array}{l}0.090 * * * \\
(0.001)\end{array}$ & $\begin{array}{l}0.069 * * * \\
(0.001)\end{array}$ & - \\
\hline $\begin{array}{l}\text { Total employment } \\
\text { experience, squared/100 }\end{array}$ & $\begin{array}{l}-0.288^{* * * *} \\
(0.004)\end{array}$ & $\begin{array}{l}-0.228^{* * *} \\
(0.005)\end{array}$ & - \\
\hline $\begin{array}{l}\text { Employment experience } \\
\text { before completing education }\end{array}$ & - & & $\begin{array}{l}0.044^{* * *} \\
(0.001)\end{array}$ \\
\hline $\begin{array}{l}\text { Employment experience } \\
\text { before completing } \\
\text { education, squared/100 }\end{array}$ & - & - & $\begin{array}{l}-0.150^{* * *} \\
(0.006)\end{array}$ \\
\hline $\begin{array}{l}\text { Employment experience } \\
\text { after education }\end{array}$ & - & - & $\begin{array}{l}0.058^{* * *} \\
(0.001)\end{array}$ \\
\hline $\begin{array}{l}\text { Employment experience } \\
\text { after education, squared/100 }\end{array}$ & - & - & $\begin{array}{l}-0.215^{* * *} \\
(0.004)\end{array}$ \\
\hline No of individuals & 24,951 & 33,798 & 33,798 \\
\hline No of observations & 172,883 & 297,938 & 297,938 \\
\hline R-square (overall) & 0.263 & 0.405 & 0.403 \\
\hline
\end{tabular}

$* * *, * *$, and $*$ indicates significance at $1 \%, 5 \%$ and $10 \%$ level, respectively.

Note 1: All models include controls for region, educational level, occupational status, sector, and year dummies are included. 
Table 6. Fixed effects estimation of male hourly wage function, including years of marriage, cohabitation and divorce. Selected coefficients. Standard deviations in parentheses.

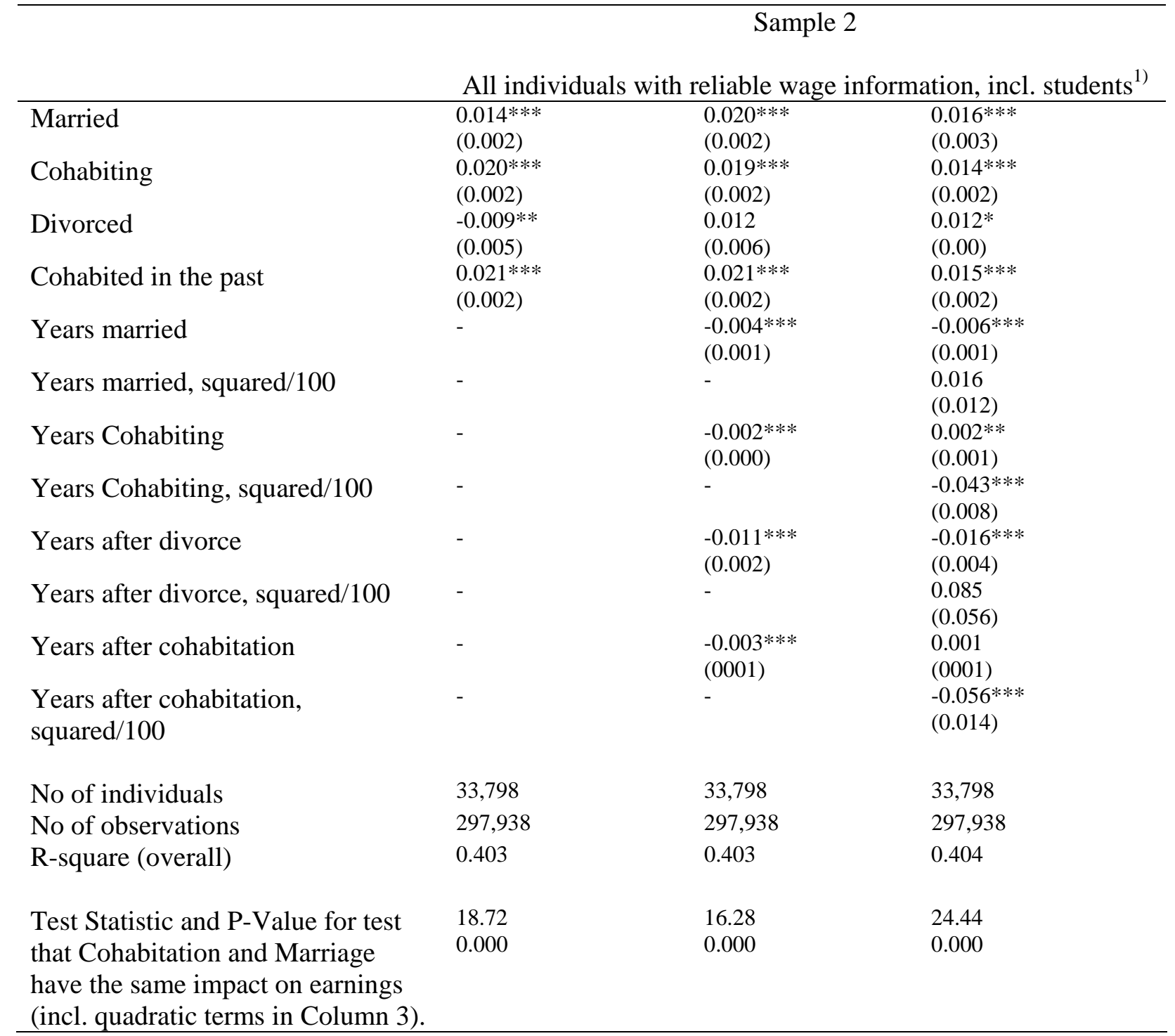

\footnotetext{
$* * *, * *$, and $*$ indicates significance at $1 \%, 5 \%$ and $10 \%$ level, respectively.
}

Note 1: All models include controls for region, educational level, employment experience prior to completing and following completion of education (and square terms), occupational status, sector, and year. 
Table 7. Estimation of male hourly wage function, including variables for children and fatherhood. Selected coefficients. Standard deviations in parentheses.

Model 3

Fixed Effects. All individuals with reliable wage information,

\begin{tabular}{|c|c|c|c|c|}
\hline \multirow[b]{2}{*}{ Married } & \multicolumn{4}{|c|}{ incl. students ${ }^{1)}$} \\
\hline & $\begin{array}{l}0.020 * * * \\
(0.002)\end{array}$ & $\begin{array}{l}0.018^{* * *} \\
(0.003)\end{array}$ & $\begin{array}{l}0.016^{* * *} \\
(0.003)\end{array}$ & $\begin{array}{l}0.012 * * * \\
(0.003)\end{array}$ \\
\hline Cohabiting & $0.019 * * *$ & $0.018^{* * *}$ & $0.018^{* * *}$ & $0.015^{* * *}$ \\
\hline Divorced & $\begin{array}{l}(0.002) \\
0.012 * \\
(0.006)\end{array}$ & $\begin{array}{l}(0.002) \\
0.012 * * \\
(0.006)\end{array}$ & $\begin{array}{l}(0.002) \\
0.008 \\
(0.006)\end{array}$ & $\begin{array}{l}(0.002) \\
0.011^{*} \\
(0.006)\end{array}$ \\
\hline Cohabiting in the past & $\begin{array}{l}0.021 * * * \\
(0.002)\end{array}$ & $\begin{array}{l}0.021 * * * \\
(0.002)\end{array}$ & $\begin{array}{l}0.020 * * * \\
(0.002)\end{array}$ & $\begin{array}{l}0.020 * * * \\
(0.002)\end{array}$ \\
\hline Years married & $\begin{array}{l}-0.004^{* * *} \\
(0.001)\end{array}$ & $\begin{array}{l}-0.005^{* * *} \\
(0.001)\end{array}$ & $\begin{array}{l}-0.003^{* * *} \\
(0.001)\end{array}$ & $\begin{array}{l}0.000 \\
(0.001)\end{array}$ \\
\hline Years Cohabiting & $\begin{array}{l}-0.002^{* * *} \\
(0.000)\end{array}$ & $\begin{array}{l}-0.002^{* * *} \\
(0.000)\end{array}$ & $\begin{array}{l}-0.002^{* * *} \\
(0.000)\end{array}$ & $\begin{array}{l}0.001 \\
(0.000)\end{array}$ \\
\hline Years after divorce & $\begin{array}{l}-0.011^{* * *} \\
(0.002)\end{array}$ & $\begin{array}{l}-0.011^{* * *} \\
(0.002)\end{array}$ & $\begin{array}{l}-0.011^{* * *} \\
(0.002)\end{array}$ & $\begin{array}{l}-0.007^{* * *} \\
(0.002)\end{array}$ \\
\hline Years after cohabitation & $\begin{array}{l}-0.003^{* * *} \\
(0001)\end{array}$ & $\begin{array}{l}-0.003^{* * *} \\
(0001)\end{array}$ & $\begin{array}{l}-0.003^{* * *} \\
(0001)\end{array}$ & $\begin{array}{l}-0.002 \\
(0001)\end{array}$ \\
\hline Years in fatherhood & - & - & - & $\begin{array}{l}-0.007 * * * \\
(0.000)\end{array}$ \\
\hline Child aged 0-17 & - & $\begin{array}{l}0.003 \\
(0.002)\end{array}$ & & $\begin{array}{l}0.009 * * * \\
(0.002)\end{array}$ \\
\hline Child aged 0-2 & - & - & $\begin{array}{l}0.009 * * * \\
(0.002)\end{array}$ & - \\
\hline Child aged 3-9 & - & - & $\begin{array}{l}-0.010^{* * *} \\
(0.002)\end{array}$ & - \\
\hline Child aged 10-17 & - & - & $\begin{array}{l}-0.012^{* * *} \\
(0.004)\end{array}$ & - \\
\hline No of individuals & 33,798 & 33,798 & 33,798 & 33,798 \\
\hline No of observations & 297,938 & 297,938 & 297,938 & 297,938 \\
\hline R-square (overall) & 0.403 & 0.404 & 0.404 & 0.404 \\
\hline $\begin{array}{l}\text { Test Statistic \& P-Value for } \\
\text { test that Cohabitation and } \\
\text { Marriage have the same } \\
\text { impact on earnings. }\end{array}$ & $\begin{array}{l}16.28 \\
0.000\end{array}$ & $\begin{array}{l}16.02 \\
0.000\end{array}$ & $\begin{array}{l}12.76 \\
0.000\end{array}$ & $\begin{array}{l}3.42 \\
0.008\end{array}$ \\
\hline
\end{tabular}


Appendix: Table A1. Sample Statistics

\begin{tabular}{|c|c|c|c|c|c|c|c|c|}
\hline & \multicolumn{3}{|c|}{ All years, pooled sample } & \multirow{2}{*}{$\begin{array}{c}1985 \\
\text { All }\end{array}$} & \multicolumn{4}{|c|}{2001} \\
\hline & All & Age 18 & Age 35 & & All & Married & $\begin{array}{c}\text { Cohabi } \\
\text { ting }\end{array}$ & Single \\
\hline Age & 25.344 & 18 & 35 & 18.408 & 30.698 & 31.900 & 30.071 & 30.081 \\
\hline Hourly Wage Rate, DKK, 1984 prices & 96.392 & 61.081 & 128.293 & 61.651 & 118.620 & 126.624 & 116.804 & 112.060 \\
\hline Rural area & 0.169 & 0.227 & 0.185 & 0.214 & 0.161 & 0.197 & 0.157 & 0.126 \\
\hline Small city & 0.564 & 0.615 & 0.582 & 0.615 & 0.545 & 0.603 & 0.533 & 0.499 \\
\hline High school & 0.125 & 0.016 & 0.063 & 0.105 & 0.076 & 0.056 & 0.074 & 0.098 \\
\hline Short theoretical or vocational educ & 0.474 & 0.008 & 0.563 & 0.045 & 0.550 & 0.564 & 0.571 & 0.513 \\
\hline Medium theoretical educ. & 0.056 & 0 & 0.114 & 0 & 0.111 & 0.120 & 0.113 & 0.099 \\
\hline University & 0.031 & 0 & 0.082 & 0 & 0.075 & 0.094 & 0.067 & 0.062 \\
\hline Raw materials & 0.048 & 0.141 & 0.025 & 0.140 & 0.027 & 0.027 & 0.026 & 0.029 \\
\hline Manufacturing & 0.273 & 0.325 & 0.282 & 0.343 & 0.259 & 0.262 & 0.264 & 0.250 \\
\hline Construction & 0.122 & 0.113 & 0.116 & 0.101 & 0.121 & 0.124 & 0.127 & 0.110 \\
\hline Service & 0.402 & 0.319 & 0.418 & 0.298 & 0.438 & 0.429 & 0.439 & 0.448 \\
\hline Other industry & 0.010 & 0.006 & 0.014 & 0.006 & 0.013 & 0.013 & 0.011 & 0.016 \\
\hline Other occupation & 0.098 & 0.423 & 0 & 0.382 & 0 & 0 & 0 & 0 \\
\hline Salaried, medium or high level & 0.011 & 0.001 & 0 & 0.001 & 0 & 0 & 0 & 0 \\
\hline Salaried, low level & 0.120 & 0.130 & 0 & 0.144 & 0 & 0 & 0 & 0 \\
\hline Skilled & 0.135 & 0.228 & 0 & 0.220 & 0 & 0 & 0 & 0 \\
\hline Child aged 3-9 years & 0.109 & 0 & 0.532 & 0.001 & 0.283 & 0.589 & 0.231 & 0.013 \\
\hline Child aged $10-17$ years & 0.015 & 0 & 0.160 & 0.001 & 0.055 & 0.107 & 0.051 & 0.004 \\
\hline $\begin{array}{l}\text { Years since individual became a father, condit. } \\
\text { on being a father }\end{array}$ & 1.010 & 0.001 & 5.784 & 0.005 & 2.741 & 4.928 & 2.137 & 1.061 \\
\hline Married & 0.153 & 0.001 & 0.535 & 0.002 & 0.341 & 1 & 0 & 0 \\
\hline Cohabiting & 0.297 & 0.015 & 0.231 & 0.037 & 0.337 & 0 & 1 & 0 \\
\hline Divorced or separated i & 0.009 & 0 & 0.044 & 0 & 0.025 & 0 & 0 & 0.077 \\
\hline Cohabitated in the past & 0.091 & 0.001 & 0.094 & 0.003 & 0.120 & 0 & 0 & 0.371 \\
\hline Years married & 0.543 & 0 & 3.643 & 0.001 & 1.590 & 4.269 & 0.128 & 0.284 \\
\hline Years cohabiting & 1.661 & 0.009 & 4.630 & 0.025 & 3.349 & 3.972 & 4.795 & 1.184 \\
\hline Years divorced or separated & 0.035 & 0 & 0.269 & 0 & 0.104 & 0.052 & 0.080 & 0.184 \\
\hline Years cohabiting in the past & 0.505 & 0.001 & 1.473 & 0.002 & 1.103 & 0.660 & 1.124 & 1.548 \\
\hline No of observations & 297,938 & 8576 & 2959 & 3211 & 25,548 & 8707 & 8598 & 8243 \\
\hline No of individuals & 33,798 & 8576 & 2959 & 3211 & 25,548 & 8707 & 8598 & 8243 \\
\hline
\end{tabular}

